\title{
Conservation and management of humpback dolphins: the South African perspective*
}

\author{
Leszek Karczmarski
}

\begin{abstract}
Population biology and socio-ecology of Indo-Pacific humpback dolphins Sousa chinensis were investigated during a 3-year study period in the Algoa Bay region, South Africa. The dolphins inhabit a narrow strip of coastal waters, mostly less than $15 \mathrm{~m}$ deep. Groups are small (mean $=7$ animals) and their daily activities concentrate around shallow rocky reefs-the primary feeding grounds. Dependence on these restricted, shallow-water habitats is evident throughout the year. Site fidelity is generally weak and is subject to seasonal migration, although female site fidelity seems to be related to reproductive stage. Births occur predominantly in summer. The social system is highly fluid, structured to some degree by sex and age, 'matesearching' behaviour being the most likely male reproductive strategy. The dolphins inhabiting Algoa Bay are part of a substantially larger population that uses a considerable length of the coastal zone. Estimated popu-
\end{abstract}

\section{Introduction}

Humpback dolphins (genus Sousa, also referred to as hump-backed dolphins, e.g. Klinowska, 1991) (Plate 1) inhabit the coastal waters of the Indo-Pacific region [Sousa chinensis (Osbeck, 1765)] and tropical west Africa [Sousa teuszii (Kukenthal, 1892)] (Ross et al., 1994; Jefferson \& Karczmarski, 2000). The inshore distribution of humpback dolphins renders them particularly susceptible to the effects of human activities in the coastal zone. These include fishing with gill or seine nets, pollution arising from coastal run-off and general degradation of inshore habitats (Klinowska, 1991; Cockcroft \& Krohn, 1994; Lal Mohan, 1994; Reeves \& Leatherwood, 1994; Ross et al., 1994; Hale, 1997). Little is known, however, about the scale of human-caused

\footnotetext{
* The research presented in this paper was conducted in collaboration with the Centre for Dolphin Studies, Port Elizabeth Museum, PO Box 13147, Humewood 6013, South Africa and the Department of Zoology, University of Port Elizabeth, PO Box 1600 , Port Elizabeth 6000 , South Africa.

Leszek Karczmarski Current contact address: Marine Mamma Research Program, Texas A\&M University at Galveston, 4700 Avenue U, Bldg. 303, Galveston, TX 77551-5923, USA. Fax: +1409 7404717; e-mail: karczmal@tamug.tamu.edu
}

Revised manuscript accepted for publication 3 March 2000 lation parameters are generally low, as are modelled population growth rates, and an increase in the population size seems unlikely. Humpback dolphins appear to be vulnerable to negative environmental pressure and the alteration/destruction of inshore habitats is probably among the greatest threats to them. Conservation of this species should be given high priority and be seen as an important part of integrated coastal zone management. Establishment of multiple-use management areas with controlled ecotourism and several priority sites declared as strict reserves seems to be the most effective conservation approach. In order to be successful, conservation and management policies need to recognize the needs and lifestyles of the local inhabitants.

Keywords Algoa Bay, conservation, humpback dolphins, Indian Ocean, integrated coastal zone management, Sousa chinensis, South Africa.

mortality and nothing about the status of particular populations. Ecological studies of either species remain few and recent (Karczmarski, 1996; Guissamulo, 2000; Jefferson, 2000). Furthermore, the taxonomic relationships within the genus Sousa are poorly understood, with between one and five nominal species proposed (Ross et al., 1994; G. J. B. Ross, unpublished data). Both the Atlantic and the Indo-Pacific Sousa are classified by The World Conservation Union (IUCN) as 'insufficiently known' (Klinowska, 1991; Reeves \& Leatherwood, 1994), although there are indications that their continued survival may be threatened in numerous areas throughout the genus range (e.g. Cockcroft, 1990; Klinowska, 1991; Cockcroft \& Krohn, 1994; Reeves \& Leatherwood, 1994).

In South Africa, a major cause of humpback dolphin mortality is gill nets set to deplete the number of large sharks off the KwaZulu-Natal coast in an attempt to protect the main bathing beaches (Cockcroft, 1990, 1994). Furthermore, humpback dolphins seem to accumulate high concentrations of toxic organochlorines (V. G. Cockcroft, unpublished data) which may affect their health, including reproductive capacity. As in the case of other dolphins, females probably accumulate lipophilic pollutants up to the age of sexual maturity, whereupon primiparous females transfer a large pro- 
portion of their total pollution load to their offspring through lactation. This may be fatal to a newborn calf (Cockcroft et al., 1989).

It has been suggested (Cockcroft, 1990) that mortalities from incidental entanglements and other sources may be close to or exceed the likely replacement rate of the humpback dolphin population in the KwaZuluNatal region. Assessment of the level of impact is not possible, however, without unbiased estimates of population parameters. Subsequently, three field research projects, in KwaZulu-Natal (Durham, 1994), Algoa Bay, Eastern Cape (Karczmarski, 1996) and Maputo Bay, Mozambique (Guissamulo, 2000), were initiated. The primary aim of this research is to study the ecology and population biology of humpback dolphins and the problems the species faces along the southeast coast of southern Africa. The ultimate goal is to provide sufficient data to enable the development of an effective conservation and management plan for this coastal dolphin species.

The study in the Algoa Bay region (Karczmarski, 1996) focused on an unexploited humpback dolphin population from an area known to be its habitat for many decades. Consequently, it provided the necessary baseline data with which to compare data from areas heavily impacted by various human activities. The present paper summarizes the findings of the Algoa Bay study and considers the implications for conservation and management.

\section{The Algoa Bay case study}

\section{Study area and methods}

Algoa Bay is the easternmost and largest of several

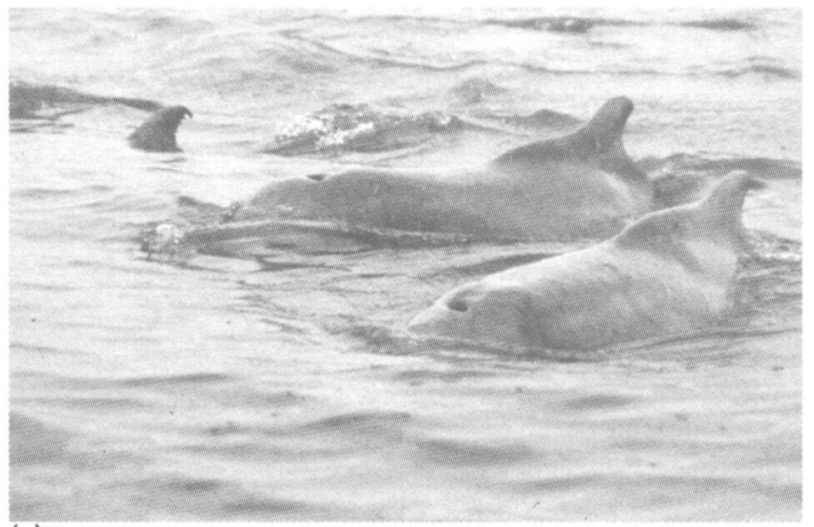

(a) log-spiral bays found on the south-east coast of South Africa (Fig. 1). The Bay, flanked by Cape Recife $\left(34^{\circ} 02^{\prime} \mathrm{S}, 25^{\circ} 42^{\prime} \mathrm{E}\right)$ on the west and Cape Padrone $\left(33^{\circ} 46^{\prime} \mathrm{S}, 26^{\circ} 28^{\prime} \mathrm{E}\right)$ on the east, is located along a generally exposed coastline and represents an open habitat with few surface geographical boundaries.

Sea- and land-based surveys were undertaken over c. $55 \mathrm{~km}$ of the south-western coast of Algoa Bay (Fig. 1) throughout a 3-year period, from May 1991 until May 1994. Daily land-based surveys started $1-2.5 \mathrm{~h}$ after sunrise (weather permitting) and were conducted by one, occasionally two, observer(s). Observations of the nearshore waters, to $c .1 \mathrm{~km}$ offshore, were carried out from several visually overlapping vantage points, with an equal level of search effort allocated to 'inshore' ( $\leq 500 \mathrm{~m}$ from shore) and 'offshore' (>500 m from shore) 'sections' of the coastal waters. Weather and sea conditions permitting, surveys in search of dolphins were repeated up to 4-5 times per day. Surveys were discontinued if the sea state exceeded Beaufort Scale 3, but were reinitiated when the weather improved.

Sea-based surveys were opportunistic, limited by both the presence of dolphins and weather conditions, and were conducted using a $3.5-\mathrm{m}$ inflatable boat powered by a $30-\mathrm{HP}$ outboard engine. The maximum possible time was dedicated to following dolphin groups and recording their membership, activities and habitat use. Dolphins were photographed using a motorized camera equipped with a variable length $(70-210 \mathrm{~mm})$ lens and 100 ASA colour positive film. Individuals were subsequently identified following the procedure described by Karczmarski \& Cockcroft (1998).

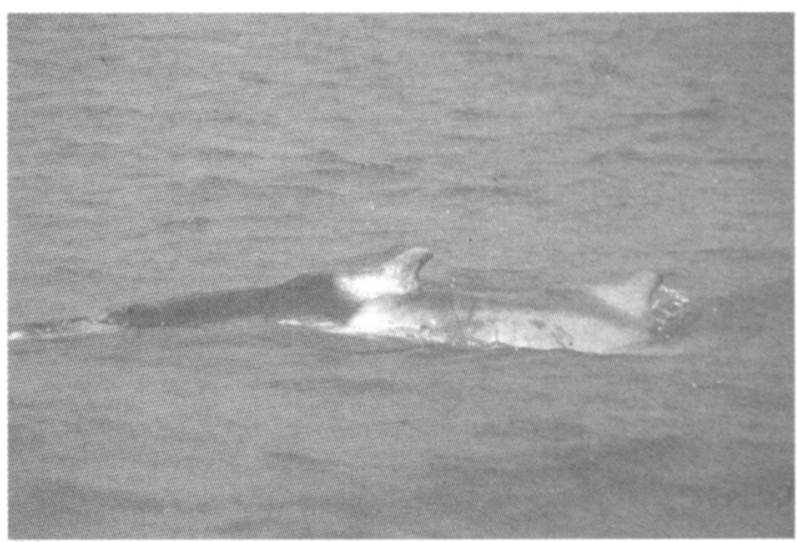

(b)

Plate 1 (a and b) The humpback dolphin is generally easily distinguished from other dolphin species in its range. The main diagnostic feature is a well-pronounced dorsal hump of connective tissue in the middle of the animal's back (the origin of the species's common name) (L. Karczmarski). 
Fig. 1 The Algoa Bay study area on the South Eastern Cape coast of South Africa.

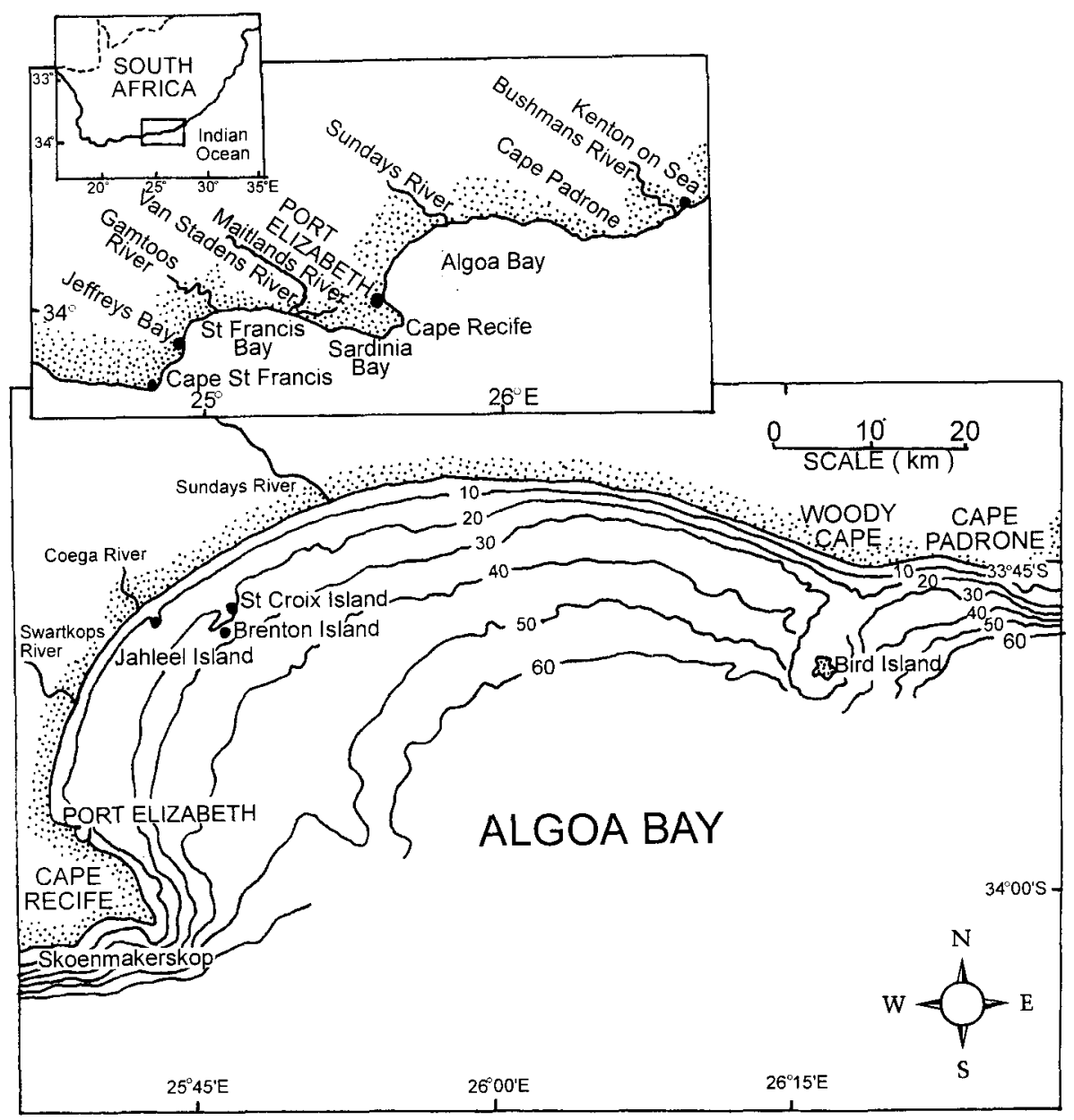

When the weather/sea conditions precluded boat surveys, dolphin activity and movement were monitored from land-based vantage points. The sea- and landbased survey procedure is described in detail in Karczmarski (1999), Karczmarski \& Cockcroft (1999) and Karczmarski et al. (1999a, 2000a, b). For comparative purposes, several boat surveys were carried out in the south-western part of St. Francis Bay, along c. $20 \mathrm{~km}$ of coastline (Fig. 1). Occasional shore-based surveys took place in Sardinia Bay, Sea View/Maitlands River beach, off Van Stadens River mouth, Gamtoos River mouth and in Jeffreys Bay (Fig. 1).

\section{Summary of results}

Over the 3-year study period, groups and solitary humpback dolphins were seen 113 times and observed for over $320 \mathrm{~h}$. The majority of these (104 times) were in Algoa Bay. Seventy-seven sea-based surveys were completed, 68 in Algoa Bay and 9 in St. Francis Bay (189 h of direct contact with dolphins). Photographs recording complete group membership (over 3000) were collected during 60 boat surveys ( $162 \mathrm{~h}$ ), of which 58 (157 h) were in Algoa Bay. A total of 70 individuals was identified and catalogued.

Daylight behaviour of humpback dolphins in Algoa Bay shows a well-defined pattern which varies little between seasons, follows the time of the solar day, and is probably governed by the diurnal cycles of dolphins' prey, with apparently little tidal impact. The dolphins can be seen in the Bay mostly in the morning, and, to a lesser extent, in the evening. Their activities are dominated by feeding, which peaks in the morning and gradually decreases through the rest of the day, with a corresponding increase in less active behaviours. There is a possible secondary increase in feeding during evenings (Karczmarski \& Cockcroft, 1999; Karczmarski et al., 2000b).

Although apparently affected little by the presence of bathers and/or surfboards, humpback dolphins frequently alter their behaviour in response to inshore boat traffic (Karczmarski et al., 1997) and on numerous 
occasions ( $n=64,95.3$ per cent of observed dolphinboat interactions) were seen actively avoiding fastmoving vessels (Karczmarski, 1996). During the sea-based surveys, it usually took at least $30 \mathrm{~min}$ of slow and cautious approach before the animals appeared to become habituated to the presence of the research boat.

The dolphins display no apparent preference for clear or turbid water. They are seen predominantly within $200-400 \mathrm{~m}$ of the shore (58.6 per cent of sightings), in water less than $15 \mathrm{~m}$ deep (91.3 percent of sightings), and were never recorded in water deeper than $25 \mathrm{~m}$. In general, water depth appears to be the main factor limiting the inshore distribution of humpback dolphins and the isobath of about $25 \mathrm{~m}$ seems to represent the critical depth (Karczmarski et al., 2000a).

Dolphin activity is not evenly distributed over the Algoa Bay coastal zone and a preference for shallow rocky reefs is evident throughout the year. A quantified pattern of area use (expressed in the Coefficient of Area Use; see Karczmarski et al., 2000a) correlates significantly with the distribution of natural and man-made reefs, with little difference between summer and winter. Open stretches of coastline, sandy shores and areas with extensive human activity (boat traffic, tourists, etc.) are used infrequently. Furthermore, the frequency of foraging/feeding correlates significantly with the inshore reef distribution. The inshore rocky reefs represent the primary feeding grounds for humpback dolphins in Eastern Cape waters, while sandy coastlines represent 'transit zones' between different feeding grounds (Karczmarski et al., 2000a).

The pattern of area use displayed by humpback dolphins in the Algoa Bay region does not differ between seasons, suggesting that, although the inshore prey availability seems to vary seasonally (as discussed in Karczmarski, 1996; Karczmarski \& Cockcroft, 1997), areas around inshore reefs provide the largest quantity of prey and represent the key habitats for this dolphin species throughout the year. Thus, humpback dolphins appear to be dependent on a restricted type of habitat within an already restricted inshore distribution. They are, consequently, particularly vulnerable to the alteration or loss of this habitat.

The social system of humpback dolphins inhabiting the Algoa Bay region seems to be highly fluid with only casual and short-lasting affiliations, structured to some degree by the sex and age of the animals (Karczmarski, 1999). Strong bonds between individuals other than mothers and calves are uncommon. Groups are small (mean $=7$ animals) and lack of consistency in the group membership appears to be the general pattern (Karczmarski, 1999; Karczmarski et al., 1999a). The dolphins display varying, but generally weak, degrees of site fidelity. The majority of them seem to be involved in long-range movements approximating at least a few hundred kilometres (Karczmarski, 1996). It is probably the patchiness of restricted, inshore prey resources that forces the dolphins to range over long distances in search of food, resulting in a low level of fidelity to any particular area. However, in areas where prey density is high, site fidelity may be greater.

Interestingly, the degree of site fidelity displayed by female humpback dolphins is seemingly related to their reproductive stage (Karczmarski, 1999). Although both sexes are probably involved in extensive long-range movement, the physical limitations of young calves apparently force nursing females to intensify their activities over more limited areas-'nurseries'. As such 'nurseries' must provide the necessary resources for the energetic demands of lactating females, their size depends on prey availability and the strength/age of calf, and increases with calf age. Maternal care lasts at least 3-4 years. In Algoa Bay, births occur predominantly in summer and there is evidence of a 3-year calving interval (Karczmarski, 1999).

Mark-recapture analyses carried out on the photoidentification data indicate that humpback dolphins seen in Algoa Bay are part of a larger population which is estimated at c. 466 dolphins (Karczmarski et al., $1999 \mathrm{~b}$ ), with a relative density of 0.42 dolphins per sq km (Karczmarski, 1996). The rate of discovery of newly identified dolphins, distribution of sightings and frequency of resightings of known individuals suggest a high level of seasonal migration (Karczmarski et al., $1999 \mathrm{a}, \mathrm{b})$.

The mean annual crude birth rate is estimated to be within a range between 4.8 percent (Karczmarski, 1996) and 6.5 per cent (L. Karczmarski, unpublished data). The minimum mortality rate to the age of 1 year is $c .20$ per cent and the recruitment rate to the age of 1 year is less than 4 per cent. The annual adult survival rate can be roughly estimated at c. 95 per cent (Karczmarski, 1996). Modelled population growth rates are low, ranging between a 3 per cent decrease per annum and a 2 per cent increase (Karczmarski, 1996; L. Karczmarski, unpublished data). In the Algoa Bay region, the humpback dolphin population is probably stable, but an increase in the population size seems unlikely.

\section{Research priorities}

There are several aspects of humpback dolphin natural history that require more research in order to be understood fully. The definition of the genetic identity of the dolphins from the Algoa Bay region and the geographical range of these animals are among the most important aspects still to be investigated. On a larger scale, 
the prime need is to determine how discrete are the various groups of humpback dolphins along the South African coast. Fragmentation of a species's distribution into a number of isolated units has several detrimental implications. Generally, the probability of extinction of an isolated, local group/population is magnified greatly and varies inversely with the population size (Gilpin \& Diamond, 1976; Gilpin \& Soulé, 1986). Consequently, the high mortality of humpback dolphins along the KwaZulu-Natal coast (Cockcroft, 1990, 1994) could represent a real threat to these animals if there is little or no recruitment from other areas.

Further research combining both photo-identification surveys and genetic sampling is, therefore, necessary. Surveys should be distributed throughout the entire south and east coast of South Africa and, preferably, several sites in Mozambique. Although the genetic work has already been initiated (Goodwin-Smith, 1997), more sampling effort is required in order to provide a sufficient database for the definition of stock identity. Photoidentification work is needed in order to determine seasonal distribution and long-range movement patterns, social and geographic fidelity, geographic variation in habitat preferences and total population numbers.

These studies could well be supplemented by remote sensing, preferably using satellite transmitters. There are, however, numerous logistical problems that would need to be overcome. Sites where humpback dolphins could be captured, tagged and released with little stress to the animals are rare along the South African coast. Such operations would probably need to be conducted using several boats, and almost certainly would cause considerable stress to the animals. Nevertheless, in view of the success of this type of work elsewhere (e.g. Mate et al., 1995), it would provide valuable data on movements, range, area/habitat use and both diurnal and nocturnal activities of humpback dolphins and should be considered.

Biopsy samples, although difficult to collect from free-ranging dolphins, could provide valuable data on pollutant residue levels. These, if mapped against the assessed distribution of humpback dolphins and known distribution of pollutant sources, could be an important indicator of the health of both the dolphins and the inshore ecosystem.

Ongoing population estimates for humpback dolphins in the Algoa Bay area are needed to supplement the present data and to monitor population trends. Further research is also necessary in order to determine the sex and, possibly, age of the humpback dolphins identified in Algoa Bay. These are necessary prerequisites if models of the dynamics of the population are to be constructed. Furthermore, they are essential for the better understanding of the dolphin social structure.

\section{Implications for the conservation of humpback dolphins}

In Eastern Cape waters, humpback dolphins inhabit a narrow strip of coastal zone, occur in small numbers, have low population growth rates and depend on restricted inshore resources. Preliminary estimates of population figures for the entire South African coast are low, probably not more than 1000 animals (Karczmarski, 1996). Mortality, on the other hand, is apparently high in at least parts of the coast (Cockcroft, 1990; Cockcroft \& Krohn, 1994).

The apparently extensive, long-range movement of both sexes of humpback dolphins and the highly fluid social pattern observed in the Algoa Bay region are likely to favour a mating strategy in which males search actively for sexually active, rather than monopolizing, females (Karczmarski, 1999). This mate-searching behaviour, successful in areas of high population density, is likely to depress fertilization rates when population figures are decreasing (Whitehead, 1987; Whitehead \& Arnbom, 1987). In the worst possible scenario, with high rates of incidental entanglement and/or deliberate catch, this could lead to a 'downward spiral in population numbers' (Gilpin \& Soulé, 1986; Slooten et al., 1993). Drastic alteration or loss of dolphin critical habitats is likely to have a similar effect, reducing the population to a size at which demographic or environmental stochastic events could seriously endanger its biological existence (Gilpin \& Soulé, 1986).

Throughout most of its range in the Indian Ocean, the humpback dolphin inhabits areas of generally high human population growth and protein food deficit. The South African region is one of the rare exceptions. In most other Indian Ocean countries, artisanal inshore gill net fisheries are regarded as a cheap and efficient way of supplying protein. Expanding fisheries, however, increase the risk of dolphin entanglement. The shark fishery, which is common throughout the Indian Ocean region, is particularly destructive because it targets species similar in size to dolphins. Furthermore, where the dolphins are seen repeatedly (e.g. on preferred feeding grounds), they may also be targeted deliberately for human consumption. Indeed, several incidental and possibly direct catches of Indo-Pacific humpback dolphins have been documented throughout the species's range, often despite their legal protection by local authorities (e.g. Cockcroft \& Krohn, 1994; Lal Mohan, 1994; Reeves \& Leatherwood, 1994; Cockcroft et al., 1997; Hale, 1997; L. Karczmarski, personal obs.) (Plate 2). It seems apparent that, at least in some areas, humpback dolphins may not be able to withstand such environmental pressure (e.g. Cockcroft, 1990; Durham, 1994). 
Appropriate fishery management is the only way to reduce dolphin mortality in fishing gear. Strict control over the number of boats operating in any one area and the use of target-specific fishing gear are the minimum measures that the local marine and fishery authorities need to implement diligently. Restrictive use of shark nets or even their ban, at least in some areas, may be necessary. However, indigent local fishermen are unlikely to support conservation and management efforts in the absence of some benefit. As pointed out by Johannes \& Hatcher (1986), 'conservation issues can not be expected to rate high concern among people whose basic economic and nutritional needs are not being met'. A number of conservation and management policies that work in western cultures are unlikely to be successful in many of the Indian Ocean developing countries. Conservation of humpback dolphins and other inshore cetaceans in the Indian Ocean region needs, therefore, to begin with environmental education at the local community level. Such actions need to highlight the long-term advantages of conservation

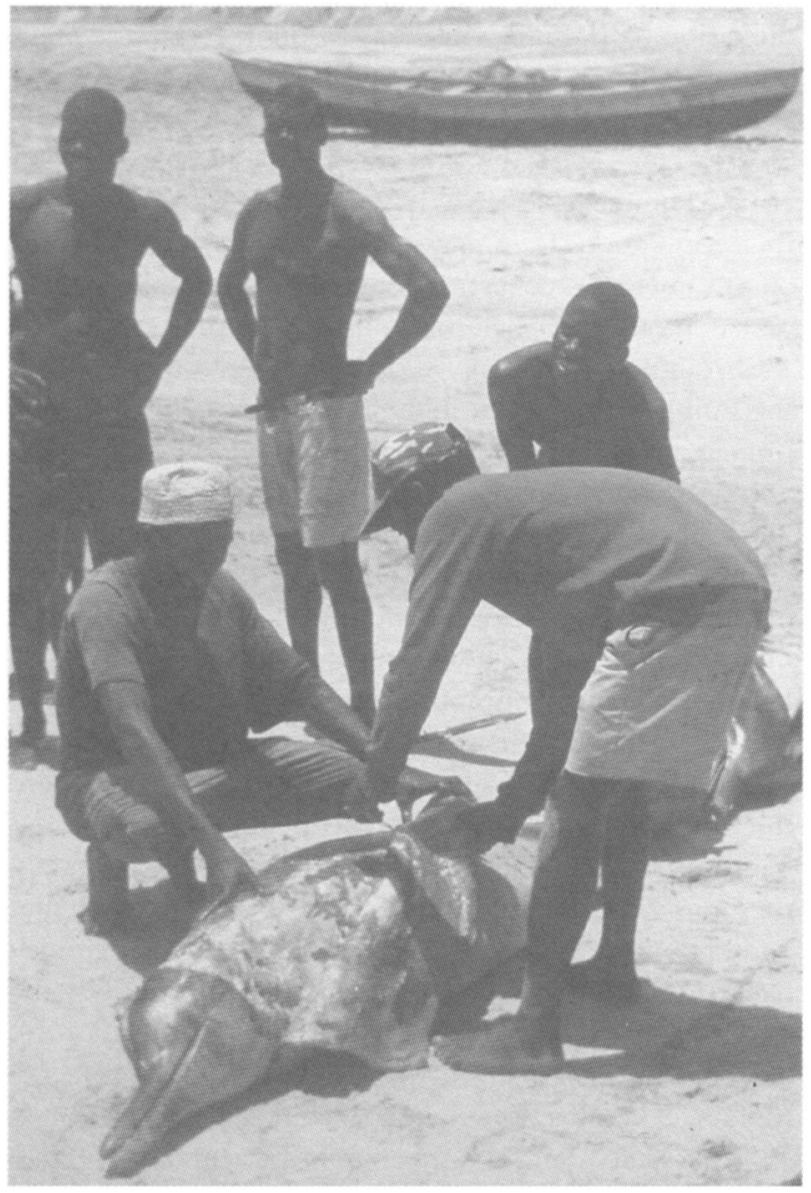

Plate 2 Humpback dolphins, apparently victims of bycatch, processed ashore in Moebase Beach, Pebane District, Zambezia Province, Mozambique (T. Wooldridge, University of Port Elizabeth, South Africa). and the sustainable use of coastal resources. Support of traditional, local authorities is vital because they carry considerably more weight in remote, isolated fishing villages than do government edicts.

Coastal contamination is a growing source of concern throughout the Indian Ocean (Obura et al., 1996). Furthermore, the long life span of humpback dolphins and their position at the top of the coastal food chain contributes to pollutant accumulation. The residue levels of chlorinated hydrocarbons (PCBs, DDT and dieldrin) in humpback dolphins from the KwaZulu-Natal coast were reported to be higher than in any other marine mammal from the region (Cockcroft, 1989; Cockcroft et al., 1991; De Kock et al., 1994). These pollutants are known to be strongly immunosuppressive (Vos \& De Roy, 1972), possibly carcinogenic (Martineau et al., 1994) and cause severe reproductive abnormalities (Reijnders, 1980; Subramanian et al., 1987). As both DDT and PCBs are in widespread use in many African and Asian countries, it is unlikely that the levels of coastal contamination will decrease in the foreseeable future. More effective disposal of these materials, although difficult to control, is needed urgently.

As pointed out by Wells (1993), 'there are likely limits to the adaptability of dolphins to habitat deterioration'. This seems to be especially so when the species's distribution is limited to a narrow strip of coastal waters where many human activities concentrate, as is the case for humpback dolphins. The generally low level of site fidelity of the dolphins from the Algoa Bay region may possibly minimize their exposure to any one problem area. On the other hand, their apparent extensive long-range movement exposes them to the adverse effects of many human activities in various parts of the coastal zone. Consequently, to be effective, conservation measures cannot be restricted to a limited area, but need to consider the coastal zone of the entire region. This also applies to many other areas, including locations where the animals are apparently far more resident than these from Algoa Bay (Durham, 1994; Guissamulo, 2000).

The destruction of inshore habitats represents probably the greatest threat to humpback dolphins. Both the habitat quantity and quality need to be considered. The habitat quantity scales the total population size and may influence aspects of its distribution. The habitat quality or, in other words, the ecological status of the environment, abundance of resources (food, shelter, breeding sites, etc.) and degree of disturbance, determines the adaptedness of the species and the probability of its survival (Gilpin \& Soulé, 1986). Consequently, the conservation of humpback dolphins needs to be seen as an integral component of the conservation and management of the coastal zone ecosystem. Where this 
is not sufficiently appreciated, the coastal ecosystem deteriorates, as do inshore delphinid populations (Simmonds \& Hutchinson, 1996).

Identification and subsequent protection of areas and habitats critical to dolphins are ways of ensuring a sufficient amount of space, shelter and food for the animals. In Eastern Cape waters, the inshore, shallow reefs need to be recognized as the habitat of primary importance for humpback dolphins. Along the KwaZulu-Natal coast, these animals seem to prefer the vicinity of large estuarine systems (Durham, 1994). In Maputo Bay, Mozambique, humpback dolphins avoid areas with extensive human activities and are seen predominantly in the western part of the Bay. In this shallow-water habitat, heavily influenced by tides, the dolphins move along tidal channels and feed predominantly over coral reefs, seagrass beds and in sheltered areas where they use the bottom topography to increase the feeding efficiency (Guissamulo, 1993, 2000; Guissamulo \& Cockcroft, 1997), as also seems to be the case for humpback dolphins in the lagoon system of Lamu, northern Kenya (L. Karczmarski, personal obs.). Similar habitat preferences, but also including mangrove areas and coastal lagoons, are reported for several locations in the Indian Ocean region (Ross et al., 1994).

It is apparent, therefore, that a large-scale alteration of coastal habitats can have detrimental effects on humpback dolphins through the destruction of dolphin feeding grounds and/or reduction of the nursery areas of dolphin prey species. Destruction or alteration of rocky shorelines, siltation and eutrophication of large estuarine systems and coastal lagoons, destruction of mangroves, seagrass beds and coral reefs are all likely to have a similar effect on humpback dolphins. Furthermore, there are several important interactions that occur between mangroves, coral reefs and tropical seagrass beds. Anything that adversely affects one of these communities may ultimately impact the others, and synergistic effects are inevitable (Ogden \& Gladfelter, 1983; Johannes \& Hatcher, 1986; Rützler \& Feller, 1987). In an attempt to conserve any of these communities, integrated coastal zone management must be practised. To be successful, however, it needs to start with changes in coastal agriculture and land use management.

Marine parks, conservation areas and reserves are recognized as a way of protecting coastal ecosystems and coastal cetaceans (e.g. Slooten \& Lad, 1991; Marsh et al., 1993). Criteria for selection and delineation of such areas are, however, not yet well developed. Furthermore, a number of specific factors need to be considered in the establishment of marine protected areas if they are to be effective in the conservation and management of marine mammals (Cockcroft \& Karczmarski, 1997). The most effective approach seems to be the protection of species and their habitats as part of large, multiple-use management areas (Marsh et al., 1993) with several priority sites declared as strict reserves (Salm \& Clark, 1989; Karczmarski et al., 1998).

Our limited knowledge of the natural history of humpback dolphins (Karczmarski, 1996) indicates that the existing southern African marine-protected areas are too small to be viable for conservation of this species. To serve such a purpose, these protected areas would need to cover several hundred kilometres of coast. The type of critical inshore habitat that should be considered for the establishment of strict reserves within protected areas-sites where human impact would be particularly restricted-will obviously vary between geographical locations and need to be identified through dedicated surveys. Nevertheless, in view of the known habitat requirements of humpback dolphins, protected areas need to encompass a maximum possible number of inshore reefs, a fairly extensive estuarine system and/or - in the tropics and subtropics-several mangrove-based coastal lagoons. The seaward boundary of such protected areas needs to be at least at the $25-\mathrm{m}$ isobath.

Furthermore, it is apparent that humpback dolphins are sensitive to disturbance, and powerboat traffic has been identified as a serious disturbance factor. Consequently, coastal developments that include an increase in inshore boating should be planned carefully. Developed coastal urban areas may require the establishment of 'go slow' zones with restricted recreational boating (e.g., see Karczmarski et al., 1998).

Existing and planned marine protected areas and conservation zones should be re-examined in view of their viability for conserving the species they are meant to protect. In the Indian Ocean region, efforts ensuring the continuous survival of humpback dolphins should be given high priority among conservation activities. Conservation and management measures need to be addressed on an international level (e.g. northern KwaZulu-Natal and southern Mozambique regions). In view of cetacean conservation and management, it is essential that the establishment of new marine conservation areas be preceded by appropriate research through which the dolphin species inhabiting the 'would be' marine park, their preferred areas and critical habitats could be identified. The possible range of local dolphin communities/populations and their residence pattern should be determined and considered when establishing the size of the conservation/management zone.

The effort of conserving humpback dolphins can ideally supplement and enforce the call for sustainable 
use of the coastal marine environment and conservation of its biodiversity. There is probably no better example of the so-called 'charismatic megafauna' which could be used as the 'flagship species' for coastal conservation in the Indian Ocean than the humpback dolphin and, possibly, the dugong Dugong dugong. Both species, if understood as integral elements of the coastal ecosystem, form an ideal bedrock upon which fundraising for conservation can be based. Furthermore, given adequate legislation and proper, regulated management, humpback dolphins could represent a valuable resource which could be exploited for ecotourism (Karczmarski et al., 1998). Dolphin watching, which is still a relatively novel idea in the African region, could create an income and stimulate further interest in coastal conservation.

Dolphin watch operations, however, would need to be preceded by an appropriate feasibility study and, for boat-based dolphin watching, an assessment of the area's carrying capacity (e.g. Karczmarski et al., 1998). Furthermore, when initiated, boat-based dolphin watch operations would need to be conducted carefully and with an appropriate knowledge of dolphin behaviour, to avoid disturbance of the animals involved. Moreover, the dolphin calving season would need to be considered, as young and inexperienced calves are likely to be particularly susceptible to various disturbance factors (e.g. Karczmarski et al., 1998; Constantine, 1999).

In some coastal areas, the processes of urbanization and industrialization may clash with the conservation effort. Although such problems are seldom easy to overcome, the 'recreational value' of humpback and other coastal dolphins may help in justifying the need for conservation. In the Algoa Bay region, the known ecological requirements of humpback dolphins (Karczmarski, 1996; Karczmarski et al., 1998, 2000a) have been a powerful and successful argument in the debate concerning coastal urban and commercial development (L. Karczmarski, unpublished data).

Learning about the ecological requirements of the species in general and the local population in particular is the only way of formulating conservation options. As pointed out by Wells (1993), wise decisions by management agencies can only be based on sound information from the field. Although the relative importance of the various environmental stressors is likely to differ between geographical regions, the type of pressure humpback dolphins are subjected to is probably similar throughout the species's range. Extensive siltation of the coastal zone because of bad land management, for example, is likely to be greater in less-developed regions, whereas industrial pollution and powerboat harassment will dominate in urban areas of developed countries. Habitat loss, over-exploitation of inshore resources and high mortality in gill nets, on the other hand, seem to be common throughout the Indian Ocean region. Consequently, the specifics of the conservation approach in various areas will differ, but not the general strategies. The ideas presented here may prove useful, therefore, for the development of adequate policies for the conservation of humpback dolphins in South Africa as well as other countries of the Indian Ocean and Indo-Pacific regions and, possibly, west Africa.

\section{Acknowledgements}

The financial assistance of the Foundation for Research Development (FRD), the Worldwide Fund for Nature (WWF)-South Africa and the University of Port Elizabeth is gratefully acknowledged. Victor Cockcroft (Centre for Dolphin Studies, Plettenberg Bay, South Africa), Deo Winter (University of Port Elizabeth, South Africa), Graham Ross (Australian Biological Resources Study, Canberra, Australia), Anton McLachlan (College of Science, Sultan Qaboos University, Oman) and Almeida Guissamulo (Museu de História Natural, Maputo, Mozambique) provided suggestions which greatly enriched the study. Bernd Würsig, Susan Reeve, Gately Ross and an anonymous reviewer commented on an earlier draft of the manuscript.

\section{References}

Cockcroft, V.G. (1989) Biology of Indopacific humpback dolphins (Sousa plumbea) off Natal, South Africa. In Abstracts, Eighth Biennial Conference on the Biology of Marine Mammals. Pacific Grove, California, USA.

Cockcroft, V.G. (1990) Dolphin catches in the Natal shark nets, 1980 to 1988. South African Journal of Wildlife Research, 20, 44-51.

Cockcroft, V.G. (1994) Is there common cause for dolphin capture in gillnets? A review of dolphin catches in shark nets off Natal, South Africa. Reports of the International Whaling Commission, Special Issue, 15, 541-547.

Cockcroft, V.G. \& Karczmarski, L. (1997) Can dolphins benefit from conservation zones in South Africa? Custos, November, 12-14.

Cockcroft, V.G. \& Krohn, R. (1994) Passive gear fisheries off the southwestern Indian and southeastern Atlantic oceans: an assessment of their possible impact on cetaceans. Reports of the International Whaling Commission, Special Issue, 15, 317-328.

Cockcroft, V.G., De Kock, A.C., Lord, D.A. \& Ross, G.J.B. (1989) Organochlorines in bottlenose dolphins Tursiops truncatus from the east coast of South Africa. South African Journal of Marine Science, 8, 207-217.

Cockcroft, V.G., Ross, G.J.B., Connell, A.D., Gardner, B.D. \& Butler, A.C. (1991) Occurrence of organochlorines in 
stranded cetaceans and seals from the east coast of southern Africa. In Cetaceans and Cetacean Research in the Indian Ocean Sanctuary (eds S. Leatherwood and G. P. Donovan), pp. 271-276. Marine Mammal Technical Report No. 3., UNEP.

Cockcroft, V.G., Vely, M., Rakotonirina, B.P., Young, D.D. \& Karczmarski, L. (1997) Marine mammals of Madagascar (and the Comoros Islands) and their exploitation. International Whaling Commission Scientific Committee Report $\mathrm{SC} / 49 / \mathrm{SH} 18$.

Constantine, R. (1999) Effects of tourism on marine mammals in New Zealand. Science for Conservation Series 106, New Zealand Department of Conservation, Wellington

De Kock, A.C., Best, P.B., Cockcroft, V.G. \& Bosma, C. (1994) Persistent organochlorine residues in small cetaceans from the east and west coasts of southern Africa. Science of the Total Environment, 154, 153-162.

Durham, B. (1994) The distribution and abundance of the humpback dolphins (Sousa chinensis) along the Natal coast, South Africa. MSc thesis, University of Natal.

Gilpin, M.E. \& Diamond, J.M. (1976) Calculation of immigration and extinction curves from the species-area-distance relation. Proceedings of the National Academy of Sciences of the United States of America, 73, $4130-4134$.

Gilpin, M.E. \& Soulé, M.E. (1986) Minimum viable populations: processes of species extinction. In Conservation Biology: the Science of Scarcity and Diversity (ed. M. E. Soulé), pp. 19-34. Sinauer Associates, Sunderland.

Goodwin-Smith, J. (1997) Molecular genetic assessment of the population structure and variation in two inshore dolphin genera on the east coast of South Africa. PhD thesis, Rhodes University.

Guissamulo, A. T. (1993) Distribuicao e abundancia de golfinhos $e$ dugongos e suas interaccoes com algumas pescarias nas baias de Maputo e Bazaruto. Licenciatura thesis, Universidade Eduardo Mondlane, Maputo [in Portuguese].

Guissamulo, A.T. (2000) Ecological studies of bottlenose and humpback dolphins of Maputo Bay, southern Mozambique. PhD thesis, University of Natal.

Guissamulo, A.T. \& Cockcroft, V.G. (1997) Dolphin and dugong occurrence and distribution and fisheries interactions in Maputo and Bazaruto Bays, Mozambique. International Whaling Commission Scientific Committee Report $\mathrm{SC} / 49 / \mathrm{SM} 24$.

Hale, P. (1997) Conservation of inshore dolphins in Australia. Asian Marine Biology, 14, 83-91.

Jefferson, T.A. (2000) Population biology of the Indo-Pacific hump-backed dolphin in Hong Kong waters. Wildlife Monographs (in press).

Jefferson, T.A. \& Karczmarski, L. (2000) Sousa chinensis. Mammalian Species (in press).

Johannes, R.E. \& Hatcher, B.G. (1986) Shallow tropical marine environments. In Conservation Biology: the Science of Scarcity and Diversity (ed. M. E. Soulé), pp. 371-382. Sinauer Associates, Sunderland.

Karczmarski, L. (1996) Ecological studies of humpback dolphins Sousa chinensis in the Algoa Bay region, Eastern Cape, South Africa. PhD thesis, University of Port Elizabeth.
Karczmarski, L. (1999) Group dynamics of humpback dolphins Sousa chinensis in the Algoa Bay region, South Africa. Journal of Zoology, 249, 283-293.

Karczmarski, L. \& Cockcroft, V.G. (1997) Socio-ecology and population biology of humpback dolphins (Sousa chinensis) in the Algoa Bay region, South Africa: an overview. International Whaling Commission Scientific Committee Report SC/49/SM23.

Karczmarski, L. \& Cockcroft, V.G. (1998) Matrix photo-identification technique applied in studies of free-ranging bottlenose and humpback dolphins. Aquatic Mammals, 24, 143-147.

Karczmarski, L. \& Cockcroft, V.G. (1999) Daylight behaviour of Humpback dolphins Sousa chinensis in Algoa Bay, South Africa. Zeitschrift für Süugetierkunde, 64, 19-29.

Karczmarski, L., Thornton, M. \& Cockcroft, V.G. (1997) Description of selected behaviours of humpback dolphins Sousa chinensis. Aquatic Mammals, 23, 127-133.

Karczmarski, L., Cockcroft, V.G., McLachlan, A. \& Winter, P.E.D. (1998) Recommendations for the conservation and management of humpback dolphins Sousa chinensis in the Algoa Bay region, South Africa. Koedoe, 41, 121-129.

Karczmarski, L., Cockcroft, V.G. \& McLachlan, A. (1999a) Group size and seasonal pattern of occurrence of humpback dolphins Sousa chinensis in Algoa Bay, South Africa. South African Journal of Marine Science, 21, 89-97.

Karczmarski, L., Winter, P.E.D., Cockcroft, V.G. \& McLachlan, A. (1999b) Population analyses of Indo-Pacific humpback dolphins Sousa chinensis in Algoa Bay, Eastern Cape, South Africa. Marine Mammal Science, 15, 1115-1123.

Karczmarski, L., Cockcroft, V.G. \& McLachlan, A. (2000a) Habitat use and preferences of Indo-Pacific humpback dolphins Sousa chinensis in Algoa Bay, South Africa. Marine Mammal Science, 16, 65-79.

Karczmarski, L., Thornton, M. \& Cockcroft, V.G. (2000b) Daylight occurrence of humpback dolphins Sousa chinensis in Algoa Bay, South Africa. African Journal of Ecology, 38, 86-90.

Klinowska, M. (1991) Dolphins, porpoises and whales of the world. In The IUCN Red Data Book. IUCN, Gland.

Kukenthal, W. (1892) Sotalia teuszit n. sp., ein pflanzenfressender Delphin aus Kamerun. Zoologishe Jahrbuch, 6, 442-446.

Lal Mohan, R.S. (1994) Review of gillnet fisheries and cetacean bycatches in the northeastern Indian Ocean. Reports of the International Whaling Commission, Special Issue, 15, 329-343.

Marsh, H., Corkeron, P.J., Limpus, C.J., Shaughnessy, P.D. \& Ward, T.M. (1993) Conserving marine mammals and reptiles in Australia and Oceania. In Conservation Biology in Australia and Oceania (eds C. Moritz and J. Kikkawa), pp. 225-244. Surrey Beatty \& Sons, Chipping Norton.

Martineau, D., De Guise, S., Fournier, M., Shugart, L., Girard, C., Lagace, A. et al. (1994) Pathology and toxicology of beluga whales from the St. Lawrence estuary, Quebec, Canada. Past, present and future. Science of the Total Environment, 154, 201-215.

Mate, B.R., Rossbach, K.A., Nieukirk, S.L., Wells, R.S., Irvine, A.B., Scott, M.D. et al. (1995) Satellite-monitored movements and dive behavior of a bottlenose dolphin (Tursiops truncatus) in Tampa Bay, Florida. Marine Mammal Science, 11, 452-463. 
Obura, D., Ilangakoon, A., Jayewardene, H. \& Stone, G. (eds) (1996) Integrating marine conservation in the Indian Ocean: 1996 and beyond. Report of the Indian Ocean Conservation Program Workshop, Mombasa, Kenya, 1995. New England Aquarium, Boston.

Ogden, J.C. \& Gladfelter, E.H. (1983) Coral reefs, seagrass beds and mangroves: their interaction in the coastal zone of the Caribbean. UNESCO Reports in Marine Science 23.

Osbeck, P. (1765) Reise nach Ostindien und China. Koppe, Rostok.

Reeves, R.R. \& Leatherwood, S. (1994) Dolphins, Porpoises And Whales: 1994-1998 Action Plan for the Conservation of Cetaceans. IUCN, Gland.

Reijnders, P.J.H. (1980) Organochlorine and heavy metal residues in harbour seals from the Wadden Sea and their possible effects on reproduction. Netherlands Journal of Sea Research, 14, 30-65.

Ross, G.J.B., Heinsohn, G.E. \& Cockcroft, V.G. (1994) Humpback dolphins Sousa chinensis (Osbeck, 1765), Sousa plumbea (G. Cuvier, 1829) and Sousa teuszii (Kukenthal, 1892). In Handbook of Marine Mammals, Vol. 5: The First Book of Dolphins (eds S. H. Ridgway and R. Harrison), pp. 23-42. Academic Press, San Diego.

Rützler, K. \& Feller, I.C. (1987) Mangrove swamp communities. Oceanus, 30, 76-84.

Salm, R.V. \& Clark, J.R. (1989) Marine and Coastal Protected Areas: A Guide for Planners and Managers. IUCN, Gland.

Simmonds, M.P. \& Hutchinson, J.D. (eds) (1996) The Conservation of Whales and Dolphins. John Wiley \& Sons, Chichester.

Slooten, E. \& Lad, F. (1991) Population biology and conservation of Hector's dolphin. Canadian Journal of Zoology, 69, 1701-1707.

Slooten, E., Dawson, S.M. \& Whitehead, H. (1993) Associations among photographically identified Hector's dolphins. Canadian Journal of Zoology, 71, 2311-2318.

Subramanian, A.N., Tanabe, S., Tatsukawa, R., Saito, S. \& Miyazaki, N. (1987) Reduction in the testosterone levels by PCBs and DDE in Dall's porpoises of the northwestern north Pacific. Marine Pollution Bulletin, 18 643-646.
Vos, J.G. \& De Roy, T. (1972) Immuno suppressive activity of a polychlorinated biphenyl preparation on the humoral immune response in guinea pigs. Toxicology and Applied Pharmacology, 21, 549-555.

Wells, R.S. (1993) The marine mammals of Sarasota Bay. In Sarasota Bay: 1992 Framework for Action (eds P. Roat, C. Ciccolella, H. Smith and D. Tomasko), pp. 9.1-9.23. Sarasota Bay National Estuary Program, Sarasota.

Whitehead, H. (1987) Social organization of sperm whales off the Galapagos: implication for management and conservation. Reports of the International Whaling Commission, 37, 195-199.

Whitehead, H. \& Arnbom, T. (1987) Social organization of sperm whales off the Galapagos Islands, February-April 1985. Canadian Joumal of Zoology, 65, 913-919.

\section{Biographical sketches}

Leszek Karczmarski is a Polish-born marine biologist, educated in Poland (MSc), the Netherlands, and South Africa $(\mathrm{PhD})$. Currently he is working with the Marine Mammal Research Program and Texas Institute of Oceanography at Texas A\&M University at Galveston. His primary research interest focuses on population biology and socio-ecology of delphinid cetaceans, with particular emphasis on animalhabitat interactions on a population level. He has conducted large-scale, multidimensional field studies on humpback (Sousa chinensis) and bottlenose (Tursiops truncatus aduncus) dolphins in South Africa, and spinner dolphins (Stenella longirostris) in Midway Atoll, central Pacific. In addition, he has been involved in several marine mammal and coastal conservation projects in South Africa, Mozambique, Kenya, Madagascar, the Bahamas, Belize, Hawaii and the Peruvian Amazon. Ecosystem management and long-term biological conservation of its mammalian component represent an integral part of all his past and present research. 